Published in final edited form as:

Arch Toxicol. 2016 July ; 90(7): 1695-1707. doi:10.1007/s00204-015-1586-6.

\title{
HEXABROMOCYCLODODECANE AND TETRABROMOBISPHENOL A ALTER SECRETION OF INTERFERON GAMMA (IFN $\gamma$ ) FROM HUMAN IMMUNE CELLS
}

\author{
Haifa Almughamsi and Margaret M. Whalen \\ Department of Chemistry, Tennessee State University, Nashville, TN 37209
}

\begin{abstract}
Hexabromocyclododecane (HBCD) and tetrabromobisphenol A (TBBPA) are brominated flame retardant compounds used in a variety of applications including insulation, upholstery, and epoxy resin circuit boards. Interferon gamma (IFN $\gamma$ ) is an inflammatory cytokine produced by activated $\mathrm{T}$ and NK cells that regulates immune responsiveness. HBCD and TBBPA are found in human blood and previous studies have shown that they alter the ability of human natural killer (NK) lymphocytes to destroy tumor cells. This study examines whether HBCD and TBBPA affect the secretion of IFN $\gamma$ from increasingly complex preparations of human immune cells; purified NK cells, monocyte-depleted (MD) peripheral blood mononuclear cells (PBMCs), and PBMCs. Both HBCD and TBBPA were tested at concentrations ranging from $0.05-5 \mu \mathrm{M}$. HBCD generally caused increases in IFN $\gamma$ secretion after $24 \mathrm{~h}, 48 \mathrm{~h}$, and 6 day exposures in each of the different cell preparations. The specific concentration of HBCD that caused increases as well as the magnitude of the increase varied from donor to donor. In contrast, TBBPA tended to decrease secretion of IFN $\gamma$ from NK cells, MD-PBMCs and PBMCs. Thus, exposure to these compounds may potentially disrupt the immune regulation mediated by IFN $\gamma$. Signaling pathways that have the capacity to regulate IFN $\gamma$ production (nuclear factor kappa B (NFKB), p44/42, p38, JNK) were examined for their role in the HBCD-induced increases in IFN $\gamma$. Results showed that the p44/42 (ERK1/2) MAPK pathway appears to be important in HBCD-induced increases in IFN $\gamma$ secretion from human immune cells.
\end{abstract}

\section{Keywords}

Hexabromocyclododecane; Tetrabromobisphenol A; immune cells; p44/42

\section{INTRODUCTION}

Interferon-gamma (IFN $\gamma$ ) is a pro-inflammatory cytokine secreted by $\mathrm{T}$ cells, natural killer (NK) cells (NK), and monocytes ((Billiau and Matthys, 2009; Darwich et al., 2008; Kraaij et al., 2014). It regulates the inflammatory response in a sophisticated manner, including activation of growth and differentiation of T-cells, B-cells, macrophages, and NK cells (Schroder et al., 2004). In order to prevent loss of immune capability or the increased risks

Please address all correspondence to: Dr. Margaret M. Whalen, Department of Chemistry, Tennessee State University, 3500 John A. Merritt Blvd., Nashville, TN 37209 (T) 615-963-5247 (F) 615-963-5326 (E) mwhalen@tnstate.edu. 
associated with chronic inflammation, careful regulation of IFN $\gamma$ is required (Zaidi \& Merlino, 2011). Depending on the specific circumstances IFN $\gamma$ may behave both in a protumorigenic and an antitumor manner. Cancer development will be avoided when IFN $\gamma$ increases tumor cell death by macrophages, T cells, and NK cells. However, cancer could occur when there is stimulation of myeloid derived suppressor cell development by IFN $\gamma$ (Zaidi \& Merlino, 2011). IFN $\gamma$ has the ability to cause chronic inflammation, which has been shown to further the development of some cancers such as gastrointestinal cancers (Macarthur et al., 2004).

Hexabromocyclododecane (HBCD) is a brominated flame retardant compound (Schecter et al., 2012). Expanded polystyrene, and extruded polystyrene are the main uses for this flame retardant, however it has also been used in textiles such as upholstery materials (Kajiwaraet al., 2009). HBCD exposure may have health effects on humans as it has been found in human blood serum (100 pg/g serum, which is approximately $0.16 \mathrm{nM}$ ) (Covaci et al., 2006; Knutsen et al., 2008). Studies in rats have shown that exposure to HBCD elevated liver and pituitary weight as well as cholesterol levels (van der Ven et al., 2006). Additionally, HBCD has been shown to be neurotoxic in mice (Eriksson et al., 2006). Human NK cells exposed to HBCD show decreased ability to lyse their target cells (cytolytic function) (Hinkson \& Whalen, 2009). Additionally, they show decreases in cell surface proteins needed for cytolysis and activation of the mitogen activated protein kinase (MAPK), p44/42 (ERK1/2) (Cato et al., 2014; Hinkson \&Whalen, 2010).

The flame retardant compound tetrabromobisphenol A (TBBPA) is mainly used in plastic, epoxy resin printed circuit boards, and other electronic equipment (Morose, 2006). It has been found in the environment and in wildlife such as fish (Yang et al., 2012). TBBPA has been found in human blood and tissue samples in limited amount ( 0.24 to $4.5 \mathrm{ng} / \mathrm{g}$ lipid that converts to about 0.002-0.033 nM) (Hagmar et al., 2000; Nagayama et al., 2001; Thomsen et al., 2002). Administration of TBBPA to young rats caused polycystic kidney lesions (Fukuda et al., 2004). TBBPA was able to compete with thyroid hormone, T4, for binding to human transthyretin (thyroid hormone transport protein) in vitro (Meerts et al., 2000). TBBPA, like HBCD, decreases the cytolytic function of human NK cells while decreasing cell surface proteins and activating p44/42 (Cato et al., 2014; Kibakaya et al., 2009)

IFN $\gamma$ levels are regulated by a variety of signaling pathways, including mitogen activated protein kinases (MAPKs) and nuclear factor kappa B (NFkB) (Suk et al., 2001).

Transcription regulators, CREB, ATF-2, and c-Jun, regulate IFN $\gamma$ secretion by binding to the promoter of IFN $\gamma$ to enhance gene expression in response to antigenic stimulation of T cells (Samten et al., 2008). Several factors induce CREB activation by phosphorylation including the MAPKs, p44/42 (ERK1/2) and p38 (via their activation of downstream kinases, RSKs and MAPKAP-kinases) (Shaywitz \& Greenberg, 1999).

Secretion of several pro-inflammatory cytokines is altered in response to exposure to butyltin (BT) environmental contaminants. Secretion of IFN $\gamma$ (Lawrence et al., 2015), IL-1 $\beta$ (Brown \& Whalen, 2014), and TNF-a (Hurt et al., 2013) were all affected when immune cells were exposed to the BTs tributylin (TBT) or dibutyltin (DBT). Based on these facts, it is important to examine whether the brominated flame retardant compounds, HBCD and 
TBBPA, have the ability to alter the secretion of interferon gamma IFN $\gamma$ from human immune cells.

In this study, immune cell preparations of increasing complexity were examined for the effects of HBCD and TBBPA exposures on the secretion of IFN $\gamma$. The cell preparations studied were: human NK cells, human monocyte-depleted (MD) peripheral blood mononuclear cells (PBMCs) (MD-PBMCs), and PBMCs. Using these increasingly reconstituted preparations of immune cells allows us to see whether the effects of the compounds vary dependent on the composition of the cell preparation. An additional goal of this study is to investigate signaling pathways that may be involved in any compoundinduced alterations in IFN $\gamma$ secretion. Thus, additional studies were done where MDPBMCs were pre-treated with p44/42 (ERK 1/2) pathway inhibitor, JNK pathway inhibitor, p38 inhibitor, or $\mathrm{NF \kappa B}$ inhibitor before exposure to $\mathrm{HBCD}$.

\section{MATERIALS AND METHODS}

\section{Preparation of PBMCs, and monocyte-depleted PBMCS}

PBMCs were isolated from Leukocyte filters (PALL- RCPL or RC2D) obtained from the Red Cross Blood Bank Facility (Nashville, TN) as described in Meyer et al., 2005. Leukocytes were retrieved from the filters by back-flushing them with an elution medium (sterile PBS containing $5 \mathrm{mM}$ disodium EDTA and $2.5 \%$ [w/v] sucrose) and collecting the eluent. The eluent was layered onto Ficoll-Hypaque $(1.077 \mathrm{~g} / \mathrm{mL})$ and centrifuged at $1200 \mathrm{~g}$ for $50 \mathrm{~min}$. Granulocytes and red cells pelleted at the bottom of the tube while the PBMCs floated on the Ficoll-Hypaque. Mononuclear cells were collected and washed with PBS $(500 \mathrm{~g}, 10 \mathrm{~min})$. Following washing, the cells were layered on bovine calf serum for platelet removal. The cells were then suspended in RPMI-1640 complete medium which consisted of RPMI-1640 supplemented with 10\% heat-inactivated BCS, $2 \mathrm{mML}$-glutamine and $50 \mathrm{U}$ penicillin $\mathrm{G}$ with $50 \mu \mathrm{g}$ streptomycin/mL. This preparation constituted PBMCs. Monocytedepleted PBMCs (10-20\% CD16 ${ }^{+}, 10-20 \% \mathrm{CD}^{+} 6^{+}, 70-80 \% \mathrm{CD}^{+}, 3-5 \%$ CD19 ${ }^{+}, 2-20 \%$ $\left.\mathrm{CD} 14^{+}\right)$were prepared by incubating the cells in glass Petri dishes $(150 \times 15 \mathrm{~mm})$ at $37^{\circ} \mathrm{C}$ and air/ $\mathrm{CO}_{2}, 19: 1$ for $1 \mathrm{~h}$. This cell preparation is referred to as MD-PBMCS cells.

\section{Preparation of NK cells}

NK cells were prepared from buffy coats (source leukocytes from healthy adult donors) purchased from Key Biologics, LLC (Memphis, TN). Highly purified NK cells were prepared using a rosetting procedure. RosetteSep human NK cell enrichment antibody cocktail (0.6-0.8 mL) (StemCell Technologies, Vancouver, British Columbia, Canada) was added to $45 \mathrm{~mL}$ of buffy coat. The mixture was incubated for $20 \mathrm{~min}$ at room temperature. Approximately $8 \mathrm{~mL}$ of the mixture was layered onto $4 \mathrm{~mL}$ of Ficoll-Hypaque $(1.077 \mathrm{~g} / \mathrm{mL})$ (MP Biomedicals, Irvine, CA) and centrifuged at $1200 \mathrm{~g}$ for $50 \mathrm{~min}$. NK cells were collected and washed twice with phosphate buffered saline (PBS) pH 7.2 and stored in complete media (RPMI-1640 supplemented with 10\% heat-inactivated bovine calf serum (BCS), 2 $\mathrm{m} M L$-glutamine and $50 \mathrm{U}$ penicillin $\mathrm{G}$ with $50 \mu \mathrm{g}$ streptomycin/ml) at 1 million cells $/ \mathrm{mL}$ at $37{ }^{\circ} \mathrm{C}$ and air/ $\mathrm{CO}_{2}, 19: 1$. NK cells were enriched to greater than $85 \% \mathrm{CD} 16^{+} / \mathrm{CD} 56^{+}$ 


\section{Chemical Preparation}

HBCD and TBBPA were purchased from Sigma-Aldrich (St. Louis, MO). Stock solutions were prepared as $100 \mathrm{mM}$ solutions in dimethylsulfoxide (DMSO). Desired concentrations of either HBCD or TBBPA were prepared by dilution of the stock into media.

\section{Inhibitor Preparation}

Enzyme inhibitors were purchased from Fischer Scientific (Pittsburgh, PA). Each inhibitor was prepared from stock solution in DMSO. MEK 1/2, pathway inhibitor (PD98059), p38 inhibitor (SB202190), NFKB inhibitor (BAY11-7085), and JNK inhibitor (JNK $\times$ BI78D3). All dilutions were made with cell culture media.

\section{Cell Treatments}

PBMCs, NK cells, and MD-PBMCs (at concentrations of 1.5 million cells/ mL) were treated with HBCD with appropriate DMSO control at concentrations from $0.05-5 \mu \mathrm{M}$ for $24 \mathrm{~h}, 48$ h, or 6 days. Cells were treated with TBBPA with appropriate control at concentrations from $0.05-5 \mu \mathrm{M}$ for the same lengths of incubation as used with HBCD. After the incubations, the cells were pelleted and supernatants were collected and stored at $-80 \mathrm{C}$ until assaying for IFN $\gamma$.

For pathway inhibitor experiments, monocyte-depleted PBMCs were treated with enzyme inhibitors (and appropriate control) $1 \mathrm{~h}$ prior to adding HBCD at concentrations of 2.5, 1, 0.5 $\mu \mathrm{M} \mathrm{HBCD}$ for $24 \mathrm{~h}$. After the incubations, the cells were pelleted and supernatants were collected and stored at $-70 \mathrm{C}$ until assaying for IFN $\gamma$.

\section{Cell Viability}

Cell viability was assessed at the end of each exposure period. Viability was determined using the trypan blue exclusion method. Briefly, cells were mixed with trypan blue and counted using a hemocytometer. The total number of cells and the total number of live cells were determined for both control and treated cells to determine the percent viable cells.

\section{IFN $\gamma$ Secretion Assay}

IFN $\gamma$ levels were measured using the BD OptEIA ${ }^{\mathrm{TM}}$ Human IFN $\gamma$ enzyme-linked immunosorbent assay (ELISA) kit (BD-Pharmingen, San Diego, CA). Briefly, a 96-well micro well plate, designed for ELISA (Fisher, Pittsburgh, PA), was coated with a capture antibody for IFN $\gamma$ and incubated overnight at $4{ }^{\circ} \mathrm{C}$. Following the incubation, the capture antibody was removed by washing the plate three times with wash buffer (PBS and $0.05 \%$ Tween-20). Blocking solution (PBS containing 10\% bovine calf serum) was added to each well and incubated at room temperature for $1 \mathrm{~h}$ followed by three washes. Cell supernatants and IFN $\gamma$ standards were added to the plate which was sealed and incubated for $2 \mathrm{~h}$ at room temperature. Following this incubation, the plate was washed five times and then incubated for $1 \mathrm{~h}$ with a detection antibody linked to horseradish peroxidase (HRP). The detection antibody-HRP complex was removed by seven washes and the plate was incubated for 30 min with substrate. This incubation was ended by addition of acid and the absorbance was 
measured at $450 \mathrm{~nm}$ on a Thermo Labsystems Multiskan MCC/340 plate reader (Fisher Scientific).

\section{Statistical Analysis}

Statistical analysis of the data was performed by using ANOVA and Student's test. Data were initially compared within a given experimental setup by ANOVA. A significant ANOVA was followed by pair wise analysis of control versus exposed data using Student's t test, a p value of less than 0.05 was considered significant.

\section{RESULTS}

\section{Viability of NK cells, MD-PBMCs, and PBMCs exposed to HBCD and TBBPA}

Exposure of all cell preparations to $0.05-5 \mu \mathrm{M}$ HBCD or TBBPA for all length of exposure had no significant effect on their viability as compared to the control (data not shown, available in electronic supplement).

\section{Viability of monocyte-depleted PBMCs treated with selective enzyme inhibitors and then exposed to HBCD}

Exposure of MD-PBMCs to pathway inhibitors 1 hour prior to adding the appropriate concentrations of HBCD caused no significant alterations in cell viability (data not shown, available in electronic supplement).

\section{Effects of HBCD Exposure on Secretion of IFN $\gamma$ by NK cells}

Table 1 shows the effects of exposing highly purified NK cells to $0,0.05,0.1,0.25,0.5,1$, 2.5, and $5 \mu \mathrm{M} \mathrm{HBCD}$ for $24 \mathrm{~h}, 48 \mathrm{~h}$, and 6 days on IFN $\gamma$ secretion from 4 donors $(\mathrm{KB}=\mathrm{Key}$ Biologic buffy coat). There were significant increases in IFN $\gamma$ secretion from NK cells from all donors examined after all lengths of exposure to certain concentrations of HBCD. Concentrations that caused increases varied from one donor to the next. For instance, the cells from donor KB179 showed significant increases after a $24 \mathrm{~h}$ exposure to $0.1-1 \mu \mathrm{M}$ HBCD, while NK cells from donor KB180 showed increased secretion of IFN $\gamma$ when exposed to 0.05-2.5 $\mu \mathrm{M}$ HBCD. Additionally, the magnitude of the increase in secretion varied among donors. For example, exposure to $0.1 \mu \mathrm{M}$ HBCD for $24 \mathrm{~h}$ caused a 2.7 fold increase in IFN $\gamma$ secretion in cells from KB179 while that same concentration of HBCD caused a 114 fold increase from KB180 cells. A similar pattern of results was seen after $48 \mathrm{~h}$ and $6 \mathrm{~d}$ exposures. Figure $1 \mathrm{~A}$ shows the effects of HBCD exposures on IFN $\gamma$ secretion at each of the time points for an individual donor (KB182).

\section{Effects of HBCD Exposure on Secretion of IFN $\gamma$ by MD-PBMCs}

When MD-PBMCs (predominantly NK and T cells) were exposed to HBCD for $24 \mathrm{~h}, 48 \mathrm{~h}$, and $6 \mathrm{~d}$ (F=filter obtained from the Red Cross) there were statistically significant increases in IFN $\gamma$ secretion induced at several concentrations of HBCD for all donors with variation in the fold increase among different donors (Table 2). For instance, after $24 \mathrm{~h}$, cells from F202 showed 27.4, 51.9, 18.4, 13.9, and 7.6, increases at the $0.1,0.25,0.5,1$ and $2.5 \mu \mathrm{M}$ concentrations, respectively, while F212 showed 1.9, 2.4, 3.9, 2.4, 9.8, and 5.2 fold, 
increases at those same concentrations. Figure 1B shows the effect of HBCD exposures on IFN $\gamma$ secretion at each of the time points for an individual donor (F212).

\section{Effects of HBCD Exposure on Secretion of IFN $\gamma$ by PBMCs}

PBMCs exposed to HBCD also showed significant increases in IFN $\gamma$ at all lengths of exposure (Table 3). As was seen with NK cells and MD-PBMCs, the concentrations at which significant increases occurred varied among the 5 donors tested. For instance after a $24 \mathrm{~h}$ exposure to HBCD, the cells from donor F192 treated with 0.05, 0.25, and $2.5 \mu \mathrm{M}$ HBCD showed significant increases of $1.8,2.6$, and 1.5 fold respectively after $24 \mathrm{~h}$, while cells from donor F193 showed significant increases of 10.1, 3.7, 2.6, and 2.1 fold at 0.05, $0.1,0.25$, and $2.5 \mu \mathrm{M}$ HBCD concentrations, respectively. Figure 1C shows the effects of HBCD exposures at each of the lengths of exposure for an individual donor (F189).

\section{Effects of TBBPA Exposure on Secretion of IFN $\gamma$ by NK cells}

Table 4 shows the effects of exposing highly purified NK cells to $0,0.05,0.1,0.25,0.5,1$, 2.5, and $5 \mu \mathrm{M}$ TBBPA for $24 \mathrm{~h}, 48 \mathrm{~h}$, and $6 \mathrm{~d}$ on the secretion of IFN $\gamma$. A $24 \mathrm{~h}$ TBBPA exposure caused decreases in IFN $\gamma$ secretion. Concentrations that caused decreases varied from one donor to the next. For instance, the cells from donor KB129 showed significant decreases after a $24 \mathrm{~h}$ exposure to $0.25,0.5,1$, and $5 \mu \mathrm{M}$ TBBPA, while NK cells from donor KB183 showed decreased secretion of IFN $\gamma$ when exposed to all concentrations TBBPA tested. Similar results were seen in $48 \mathrm{~h}$ and $6 \mathrm{~d}$ of exposures to TBBPA. Figure 2A shows the effects of TBBPA exposures at each of the lengths of exposure for an individual donor (F183).

\section{Effects of TBBPA Exposure on Secretion of IFN $\gamma$ by MD-PBMCs}

As with NK cells, there were significant decreases in secretion of IFN $\gamma$ from MD-PBMCs at every length of exposure to TBBPA (Table 5). Concentrations that caused decreases varied somewhat among donors. For instance, the cells from donor F175 and F177 showed significant decreases in IFN $\gamma$ secretion after exposure to $0.1-5 \mu \mathrm{M}$ TBBPA while those from F180 showed a significant decrease only at $5 \mu \mathrm{M}$. Figure 2B shows the effects of TBBPA exposures at each of the lengths of exposure for an individual donor (F177).

\section{Effects of TBBPA Exposure on Secretion of IFN $\gamma$ by PBMCs}

PBMCs showed significant decreases in IFN $\gamma$ secretion when exposed to higher concentrations of TBBPA (Table 6). Concentrations that caused decreases varied from one donor to the next at each time point. For instance, the cells from donor F188 showed significant decreases after a $24 \mathrm{~h}$ exposure to $0.5-5 \mu \mathrm{M}$ TBBPA, while PBMCs from donor F193 showed decreased secretion of IFN $\gamma$ when exposed to 0.25-5 $\mu \mathrm{M}$ TBBPA. Figure 2C shows the effects of TBBPA exposures at each of the lengths of exposure for an individual donor (F188). 


\section{Effects of HBCD Exposure on Secretion of IFN $\gamma$ by MD-PBMCs with Selective Enzyme Inhibitors}

NF $x$ B Inhibitor (BAY 11-7085)-The effects of exposures to $0.5,1$, and $2.5 \mu \mathrm{M}$ HBCD on secretion of IFN $\gamma$ from MD-PBMCs where NFkB had been inhibited with BAY 11-7085 (BAY) $(0.325 \mu \mathrm{M})$ are shown in Table 7. BAY inhibited baseline IFN $\gamma$ secretion due to its necessary role in IFN $\gamma$ production. BAY diminished the ability of HBCD to increase IFN $\gamma$ secretion from MD-PBMCs in the majority of donors. In Figure 3A (representative data from F273) we see there is 5.8 fold increases when MD-PBMCs are exposed to $2.5 \mu \mathrm{M}$ $\mathrm{HBCD}$ in the absence of $\mathrm{NF \kappa B}$ inhibitor. When the inhibitor is present this same $\mathrm{HBCD}$ exposures causes 2.2 fold increases in IFN $\gamma$ secretion. These results suggest that NFKB inhibitor may be involved HBCD-induced increases in IFN $\gamma$ secretion but its role may vary depending on the status of the donor. For all inhibitor studies the fold increase is determined from the appropriate control.

\section{Mitogen activated protein kinase kinase (MAP2K), MEK, Inhibitor (PD98059)}

The effects of exposures to $0.5,1$, and $2.5 \mu \mathrm{M}$ HBCD on secretion of IFN $\gamma$ from MDPBMCs where MEK had been inhibited with PD98059 $(50 \mu \mathrm{M})$ are shown in Table 7. PD98059 had variable effects on baseline IFN $\gamma$ secretion. Cells exposed to HBCD showed a lower fold increase in IFN $\gamma$ secretion in the presence of the inhibitor. In Figure 3B (representative data from F253) we see there are 3.1, 4.9, and 7.5 fold increases when MDPBMCs are exposed to $0.5,1$, and $2.5 \mu \mathrm{M} \mathrm{HBCD}$ in the absence of $\mathrm{p} 44 / 42$ pathway inhibitor. When the inhibitor (PD98059) is present those same HBCD exposures causes 1.5, 1.5 , and 2.5 fold increases in IFN $\gamma$ secretion. This indicates that the $\mathrm{p} 44 / 42$ pathway is a likely target of HBCD that leads to increased secretion of IFN $\gamma$.

p38 Inhibitor (SB202190)—Inhibition of p38 (SB202190, $50 \mu \mathrm{M}$ ) did not block the HBCD-induced increases in IFN $\gamma$ (Table 7). In fact it tended to increase the effect of HBCD (every donor showed an enhanced increase at a minimum of one concentration of $\mathrm{HBCD}$ ). In Figure 3C (representative data from F255) there are 2.4, 1.8, and 2.6 fold increases when MD-PBMCs are exposed to $0.5,1$, and $2.5 \mu \mathrm{M} \mathrm{HBCD}$ in the absence of $\mathrm{p} 38$ inhibitor. When the inhibitor is present, those same HBCD exposures are able to cause 9.4, 6.3, and 5.8 fold increases in IFN $\gamma$ secretion.. Thus, p38 doesn't seem to be utilized by HBCD to induce increases in IFN $\gamma$ secretion and it appears to be inhibiting the ability of HBCD to increase IFN $\gamma$.

JNK Inhibitor (BI78D3)—When JNK was inhibited by BI78D3 (0.05 $\mu \mathrm{M})$, all donors continued to show an increase IFN $\gamma$ secretion in response to HBCD (Table 7). Figure 3D, (representative data from F278) shows that there were 1.6, 3.9, and 2.2 fold increases in IFN $\gamma$ secretion when MD-PBMCs were exposed to $0.5,1$, and $2.5 \mu \mathrm{M}$ HBCD in the absence of the JNK inhibitor and 14.8, 19.1, and 3.3 fold increases in its presence. These results indicate that JNK pathway is not a target for the HBCD-induced increase in IFN $\gamma$ secretion. 


\section{DISCUSSION}

IFN $\gamma$ is a pro inflammatory cytokine and a critical immune system regulator (Schroder et al., 2004). It inhibits intracellular viral replication (Frese et al., 2002) and regulates activation of specific immune cells ((Schroder et al., 2004). Inappropriately elevated levels of it may contribute to development of atherosclerotic disease contributing to myocardial infarction and stroke (Gupta et al., 1997). HBCD and TBPPA are used as flame retardants and significantly contaminate the environment, with detectable levels being found in human tissues (Covaci et al., 2006; Knutsen et al., 2008; Hagmar et al., 2000; Nagayama et al., 2001; Thomsen et al., 2002). Both compounds are able to decrease the lytic function and cell surface protein expression of human NK cells (Hinkson \& Whalen, 2009; Hinkson \& Whalen, 2010; Kibakaya et al., 2009; Hurd \& Whalen, 2011). This inhibition of NK lytic function may be due to their ability to induce activation/phosphorylation of MAPKs and MAP2Ks (Cato et al., 2014). Other environmental contaminants such as tributyltin (TBT) and dibutyltin (DBT) (Kimbrough, 1976) that decrease NK lytic function (Dudimah et al., 2007a,b), while activating the MAPK pathway (Aluoch et al., 2006; Odman- Ghazi et al., 2010), have been shown to alter IFN $\gamma$ secretion from human immune cells (Lawrence et al., 2015). Thus, it is crucial to determine whether HBCD and TBBPA are also able to alter the secretion of IFN $\gamma$ from human immune cells.

Different donors showed varied baseline secretion of IFN $\gamma$ in each of the cell preparations. However, each of the cell preparations (PBMCs, MD-PBMCs, and NK cells) had similar responses to exposures to HBCD. For instance, when highly purified NK cells were exposed to $0.05-5 \mu \mathrm{M} \mathrm{HBCD}$, there were significant increases in secretion of IFN $\gamma$. The ability of $\mathrm{HBCD}$ to increase IFN $\gamma$ levels did not seem to change as the complexity of the cell preparations increased, as both MD-PBMCs and PBMCs also showed similar patterns of increased IFN $\gamma$ secretion in response to HBCD. Additionally, the maximum fold increase in each cell preparations (NK cells, MD-PBMCs, and PBMCs) occurred at a similar range of HBCD concentration after $24 \mathrm{~h}$. For instance, in NK cells (KB182) the range of maximum fold increases of IFN $\gamma$ secretion occurred at $0.1-1 \mu \mathrm{M}$ HBCD while in MD-PBMCs (F212) the range of maximum fold increases of IFN $\gamma$ secretion was $0.1-2.5 \mu \mathrm{M}$. The most complex cell preparation PBMCs (F193) had a maximum fold increase in the range of $(0.05-2.5 \mu \mathrm{M})$ HBCD.

In general, the secretion of IFN $\gamma$ for all cell types showed a significant decrease in response to TBBPA exposure at a minimum of one concentration and at least one length of exposure from each type of cell preparation. For instance, the cells from donor KB 129 showed significant decreases after a $24 \mathrm{~h}$ exposures to $0.25,0.5,1$, and $5 \mu \mathrm{M}$ TBBPA while the cells from MD-PBMCs donor F175 showed significant decreases after $24 \mathrm{~h}$ exposures to $0.1-5$ $\mu \mathrm{M}$ TBBPA. Additionally, the cells from PBMCs (F188) showed significant decreases after a $24 \mathrm{~h}$ exposure to $0.5-5 \mu \mathrm{M}$ TBBPA. Importantly the viability of the cells was not significantly affected by treatment with either of the compounds providing evidence that the effects on secretion were not due to death of the cells

While HBCD predominantly caused increases in IFN $\gamma$ secretion, TBBPA generally caused no change or decreases in secretion. Interestingly, HBCD and TBPA also differ in their 
capacity to activate MAPKs. HBCD is able to activate p44/42 while TBBPA activates both p44/42 and p38 (Cato et al., 2014). Thus, at least part of the difference in the effects of these 2 compounds on IFN $\gamma$ secretion may be due to their ability to differentially activate MAPKs. A previous study examining the effect of both TBT and DBT on secretion of IFN $\gamma$ from immune system cells, showed that both TBT and DBT decreased IFN $\gamma$ secretion at the highest concentrations while they both increased its secretion at lower concentrations (Lawrence et al., 2015).

After demonstrating that HBCD-induced increases in IFN $\gamma$ secretion were seen, selected inhibitors were used to determine what signaling pathway(s) may be involved in HBCDinduced alteration in IFN $\gamma$ secretion. IFN $\gamma$ secretion is known to be regulated by the p44/42 pathway in immune cells (Girart et al., 2007). It appears that the p44/42 (ERK1/2) pathway is needed for HBCD-induced increases in IFN $\gamma$ as inhibition of this pathway prior to HBCD exposure resulted in a diminished response to $\mathrm{HBCD}$. The $\mathrm{NF \kappa B}$ pathway is an important regulator of inflammatory responses, such as IFN $\gamma$ production (Oeckinghaus \& Ghosh, 2009). The current results indicate that the role of $\mathrm{NK \kappa B}$ in the HBCD-induced increases in IFN $\gamma$ secretion appears to vary depending on the donor. Previous studies have shown that additional MAPKs such as p38 and JNK also to regulate IFN $\gamma$ secretion (Rincón et al., 2000). Here we found that inhibition of either $\mathrm{p} 38$ or JNK does not block the ability of HBCD to increase IFN $\gamma$ secretion. In fact, inhibition of $\mathrm{p} 38$ caused HBCD to be more effective at increasing IFN $\gamma$ secretion. Previous studies have shown that $\mathrm{p} 44 / 42$ activation by TBT is involved in TBT-induced increases in IL-1 $\beta$ secretion (Brown \& Whalen, 2014).

It is noteworthy that the specific effects of the compounds varied in cells from different donors. The cells from all donors showed similar effects, however, the magnitude of the effect as well as the specific concentrations at which it occurred varied. This indicates that while the immune cells from all donors were affected by the compounds, there were individual differences. The concept of personalized medicine has become important in the treatment of a number of disease, most especially cancer (Madureira \& de Mello, 2014). The results from this study indicate that there may individualized responses to environmental toxicants, which may be important in assessing risk.

In summary, the current study indicates that the secretion of IFN $\gamma$ in the three human immune cell preparations studied is altered by exposures to HBCD and TBBPA. HBCD showed predominantly increases in IFN $\gamma$ secretion. TBBPA generally caused no change or decreases in secretion. These results suggest that both of these flame retardant compounds are able to disrupt secretion of IFN $\gamma$ from increasingly complex human immune cell preparations. These effects maintained even in the most complex preparation that we examined. This is important in that this preparation is more physiologically relevant. Based on that fact IFN $\gamma$ is necessary for appropriate immune response to viral infection, any decrease in IFN $\gamma$ due to exposure to these compounds could lead to an individual becoming more susceptible to viral infection. While compound-induced increases in IFN $\gamma$ may cause inappropriate inflammation. Such inflammation can lead to pathologies such as atherosclerotic disease (Gupta et al., 1997) and potentially increased tumor growth (Macarthur et al., 2004). Thus, these results may indicate that these compounds could affect 
human diseases. Additionally we showed that p44/42 MAPK is involved in the HBCDinduced increases in IFN $\gamma$ secretion.

\section{Supplementary Material}

Refer to Web version on PubMed Central for supplementary material.

\section{ACKNOWLEDGEMENT}

Grant U54CA163066 from the National Institutes of Health

\section{REFERENCES}

Aluoch A, Odman-Ghazi S, Whalen M. Alteration of an essential NK cell signaling pathway by low doses of tributyltin in human natural killer cells. Toxicology. 2006; 224:229-237. [PubMed: 16781040]

Billiau A, Matthys P. Interferon- $\gamma$ : A historical perspective. Cytokine \& Growth Factor Reviews. 2009; 20:97-113. [PubMed: 19268625]

Brown S, Whalen M. Tributyltin alters secretion of interleukin 1 beta from human immune cells. Journal of Applied Toxicology. 2014

Cato A, Celada L, Kibakaya EC, Simmons N, Whalen MM. Brominated flame retardants, tetrabromobisphenol A and hexabromocyclododecane, activate mitogen-activated protein kinases (MAPKs) in human natural killer cells. Cell Biology Toxicology. 2014; 30(6):345-360. [PubMed: 25341744]

Covaci A, Gerecke AC, Law RJ, Voorspoels S, Kohler M, Heeb NV, Leslie H, Allchin CR, De Boer J. Hexabromocyclododecanes (HBCDs) in the environment and humans: a review. Environmental science \& technology. 2006; 40:3679-3688. [PubMed: 16830527]

Darwich L, Coma G, Peña R, Bellido R, Blanco EJ, Este JA, Borras FE, Clotet B, Ruiz L, Rosell A, Andreo F, Parkhouse RM, Bofill M. Secretion of interferon- $\gamma$ by human macrophages demonstrated at the single-cell level after costimulation with interleukin (IL)-12 plus IL-18. Immunology. 2009; 126(3):386-393. [PubMed: 18759749]

Dudimah FD, Odman-Ghazi SO, Hatcher F, Whalen MM. Effect of tributyltin (TBT) on ATP levels in human natural killer (NK) cells: Relationship to TBT-induced decreases in NK function. Journal of Applied Toxicology. 2007a; 27(1):86-94. [PubMed: 17149696]

Dudimah FD, Gibson C, Whalen MM. Effect of Dibutyltin (DBT) on ATP levels in human natural killer cells. Environ. Toxicol. 2007b; 22:117-123. [PubMed: 17366562]

Eriksson P, Fischer C, Wallin M, Jakobsson E, Fredriksson A. Impaired behaviour, learning and memory, in adult mice neonatally exposed to hexabromocyclododecane (HBCDD). Environmental Toxicology and Pharmacology. 2006; 21(3):317-322. [PubMed: 21783674]

Frese M, Schwärzle V, Barth K, Krieger N, Lohmann V, Mihm S, Haller O, Bartenschlager R. Interferon-gamma inhibits replication of subgenomic and genomic hepatitis $\mathrm{C}$ virus RNAs Hepatology. 2002; 35:694-703. 2002. [PubMed: 11870386]

Fukuda N, Ito Y, Yamaguchi M, Mitumori K, Koizumi M, Hasegawa R, Kamata E, Ema M. Unexpected nephrotoxicity induced by tetrabromobisphenol A in newborn rats. Toxicology Letters. 2004; 150:145-155. [PubMed: 15093670]

Girart MV, Fuertes MB, Domaica CI, Rossi LE, Zwirner NW. Engagement of TLR3, TLR7, and NKG2D Regulate IFN- $\gamma$ Secretion but Not NKG2D-Mediated Cytotoxicity by Human NK Cells Stimulated with Suboptimal Doses of IL-12. Journal of Immunology. 2007; 179:3472-3479.

Gupta S, Pablo AM, c Jiang X, Wang N, Tall AR, Schindler C. IFN-gamma potentiates atherosclerosis in ApoE knock-out mice. Journal of Clinical Investigation. 1997; 99(11):2752. [PubMed: 9169506] 
Hagmar L, Jakobsson K, Thuresson K, Rylander L, Sjodin A, Bergman A. Computer technicians are occupationally exposed to polybrominateddiphenyl ethers and tetrabromobisphenolA. Organohalogen Comp. 2000; 47:202-205.

Hinkson NC, Whalen MM. Hexabromocyclododecane decreases the lytic function and ATP levels of human natural killer cells. Journal of Applied Toxicology. 2009; 29(8):656-661. [PubMed: 19551757]

Hinkson NC, Whalen MM. Hexabromocyclododecane decreases tumor-cell-binding capacity and cellsurface protein expression of human natural killer cells. Journal of Applied Toxicology. 2010; 30(4):302-309. [PubMed: 19938002]

Hurd T, Whalen MM. Tetrabromobisphenol A decreases cell-surface proteins involved in human natural killer (NK) cell-dependent target cell lysis. Journal of Immunotoxicol. 2011; 8(3):219-227.

Hurt K, Hurd-Brown T, Whalen M. Tributyltin and dibutyltin alter secretion of tumor necrosis factor alpha from human natural killer cells and a mixture of T cells and natural killer cells. Journal of Applied Toxicology. 2013; 33(6):503-510. [PubMed: 23047847]

Kajiwara N, Sueoka M, Ohiwa T, Takigami H. Determination of flame-retardant hexabromocyclododecanediastereomers in textiles. Chemosphere. 2009; 74(11):1485-1489. [PubMed: 19124143]

Kibakaya EC, Stephen K, Whalen MM. Tetrabromobisphenol A has immunosuppressive effects on human natural killer cells. Journal of Immunotoxicol. 2009; 6(4):285-292.

Kimbrough RD. Toxicity and health effects of selected organotin compounds: a review. Environmental Health Perspectives. 1976; 14:51. [PubMed: 789069]

Knutsen HK, Kvalem HE, Thomsen C, Froshaug M, Haugen M, Becher G, Alexander J, Meltzer HM. Dietary exposure to brominated flame retardants correlates with male blood levels in a selected group of Norwegians with a wide range of seafood consumption. Molecular Nutrition \& Food Research. 2008; 52:217-227. [PubMed: 18246586]

Kraaij MD, Vereyken EJF, Leenen PJM, van den Bosch TPP, Rezaee F, Betjes MGH, Baan CC, Rowshani AT. Human monocytes produce interferon-gamma upon stimulation with LPS. Cytokine. 2014; 67:7-12. [PubMed: 24680476]

Lawrence S, Reid J, Whalen M. Secretion of interferon gamma from human immune cells is altered by exposure to tributyltin and dibutyltin. Environmental Toxicology. 2015 In press (available online).

Macarthur M, Hold GL, El-Omar EM. Inflammation and Cancer II. Role of chronic inflammation and cytokine gene polymorphisms in the pathogenesis of gastrointestinal malignancy. American Journal of Physiology-Gastrointestinal and Liver Physiology. 2004; 286(4):G515-G520. [PubMed: 15010360]

Madureira P, de Mello RA. BRAF and MEK gene rearrangements in melanoma: implications for targeted therapy. Mol Diagn Ther. 2014; 18:285-91. [PubMed: 24403169]

Meerts IA, van Zanden JJ, Luijks EA, van Leeuwen-Bol I, Marsh G, Jakobsson E, Bergman A, Brouwer A. Potent competitive interactions of some brominated flame retardants and related compounds with human transthyretin in vitro. Toxicological Sciences. 2000; 56:95-104. [PubMed: 10869457]

Meyer TP, Zehnter I, Hofmann B, Zaisserer J, Burkhart J, Rapp S, Weinauer F, Schmitz J, Illert WE. Filter Buffy Coats (FBC): A source of peripheral blood leukocytes recovered from leukocyte depletion filters. Journal of Immunological Methods. 2005; 307:150-166. [PubMed: 16325197]

Morose, G. An overview of alternatives to tetrabromobisphenol A (TBBPA) and hexabromocyclododecane (HBCD). Lowell Center for Sustainable Production, University of Massachusetts, Lowell; 2006.

Nagayama J, Takasuga T, Tsuji H. Contamination levels of brominated flame retardants, dioxins, and organochlorine compounds in the blood of Japanese adults. Human Levels and Trends. 2001; $4: 218-221$.

Odman-Ghazi SO, Abraha A, Isom ET, Whalen MM. Dibutyltin activates MAP kinases in human natural killer cells, in vitro. Cell Biology Toxicology. 2010; 26(5):469-479. [PubMed: 20333459]

Oeckinghaus A, Ghosh S. The NF- $\kappa$ B family of transcription factors and its regulation. Cold Spring Harbor perspectives in biology. 2009; 1(4):a000034. [PubMed: 20066092] 
Rincón M, Flavell RA, Davis RA. The Jnk and P38 MAP kinase signaling pathways in T cellmediated immune responses. Free Radical Biology and Medicine. 2000; 28(9):1328-1337. [PubMed: 10924852]

Samten B, Townsend JC, Weis SE, Bhoumik A, Klucar P, Shams H, Barnes PF. CREB, ATF, and AP-1 transcription factors regulate IFN- $\gamma$ secretion by human $\mathrm{T}$ cells in response to mycobacterial antigen. The Journal of Immunology. 2008; 181(3):2056-2064. [PubMed: 18641343]

Schecter A, Szabo DT, Miller J, Gent TL, Malik-Bass N, Petersen M, Paepke O, Colacino JA, Hynan LS, Harris TR, Malla S, Birnbaum LS. Hexabromocyclododecane (HBCD) stereoisomers in U.S. food from Dallas, Texas. Environmental Health Perspective. 2012; 120(9):1260-1264.

Schroder K, Hertzog PJ, Ravasi T, Hume DA. Interferon-gamma: an overview of signals, mechanisms and functions. Journal of Leukocyte Biology. 2004; 75(2):163-189. [PubMed: 14525967]

Shaywitz AJ, Greenberg ME. Creb: a stimulus-induced transcription factor activated by a diverse array of extracellular signals. Ann. Rev. Biochem. 1999; 68:821-861. [PubMed: 10872467]

Suk K, Kim SY, Kim H. Regulation of IL-18 production by IFN $\gamma$ and PGE 2 in mouse microglial cells: involvement of NF-kB pathway in the regulatory processes. Immunology letters. 2001; 77(2):7985. [PubMed: 11377701]

Thomsen C, Lundanes E, Becher G. Brominated flame retardants in archived serum samples from Norway: A study on temporal trends and the role of age. Environmental Science Technology. 2002; 36:1414-1418. [PubMed: 11999045]

van der Ven LT, Verhoef A, van de Kuil T, Slob W, Leonards PE, Visser TJ, Hamers T, Herlin M, Håkansson H, Olausson H, Piersma AH, Vos JG. A 28-day oral dose toxicity study enhanced to detect endocrine effects of hexabromocyclododecane in Wistar rats. Toxicological Sciences. 2006; 94:281-92. [PubMed: 16984958]

Yang S, Wang S, Liu H, Yan Z. Tetrabromobisphenol A: tissue distribution in fish, and seasonal variation in water and sediment of Lake Chaohu, China. Environmental Science and Pollution Research Int. 2012; 19(9):4090-4096.

Zaidi MR, Merlino G. The two faces of interferon-gamma in cancer. Clinical Cancer Research. 2011; 17(19):6118-6124. [PubMed: 21705455] 

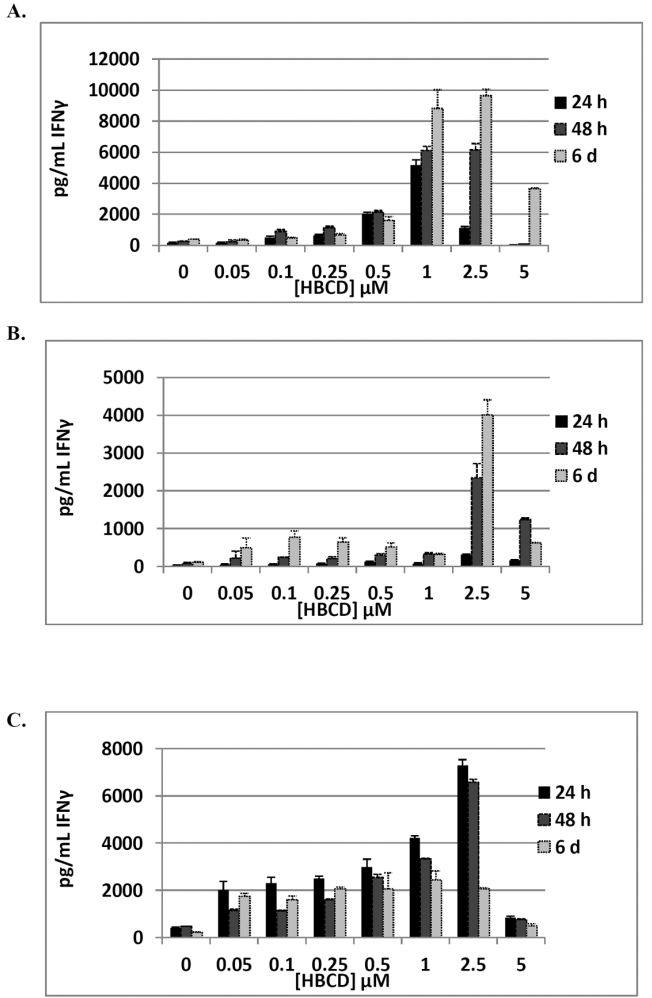

Figure 1.

Effects of $24 \mathrm{~h}, 48 \mathrm{~h}$ and 6 day exposures to HBCD on IFN $\gamma$ secretion from human NK cells, monocyte-depleted PBMCs, and PBMCs. A) NK cells exposed to 0.05-5 $\mu \mathrm{M}$ HBCD (donor KB182). B) Monocyte-depleted PBMCs exposed to 0.05-5 $\mu \mathrm{M}$ HBCD (donor F204). C) PBMCs exposed to 0.05-5 $\mu \mathrm{M}$ HBCD (donor F193). 


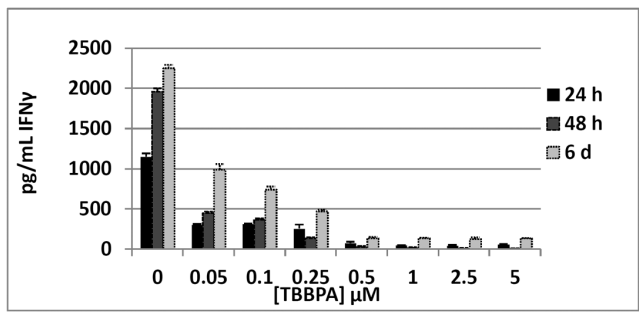

B.

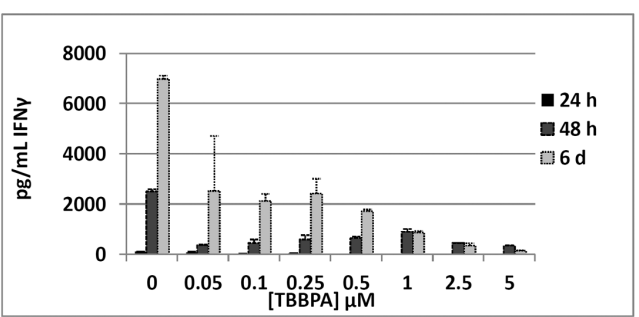

C.

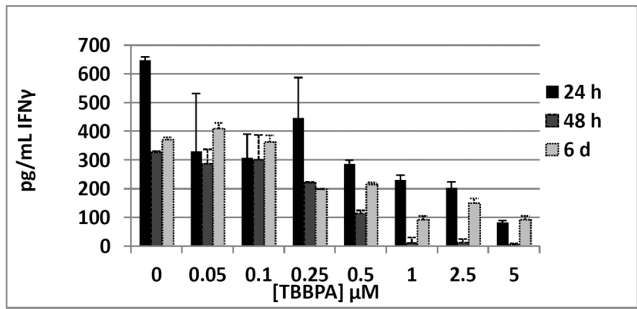

Figure 2.

Effects of $24 \mathrm{~h}, 48 \mathrm{~h}$ and 6 day exposures to TBBPA on IFN $\gamma$ secretion from human NK cells, monocyte-depleted PBMCs, and PBMCs. A) NK cells exposed to 0.05-5 $\mu \mathrm{M}$ TBBPA (donor KB183). B) Monocyte-depleted PBMCs exposed to 0.05-5 $\mu \mathrm{M}$ TBBPA (donor F180). C) PBMCs exposed to 0.05-5 $\mu \mathrm{M}$ TBBPA (donor F186). 


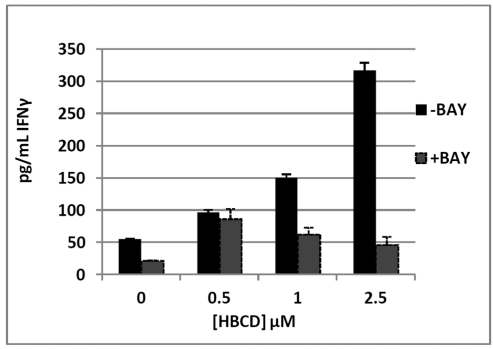

C.

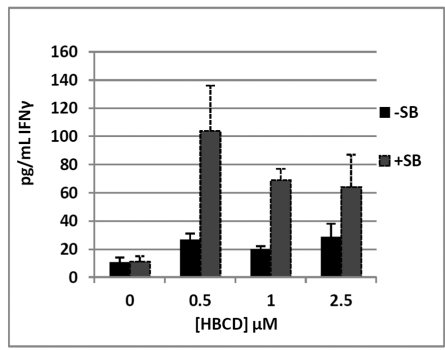

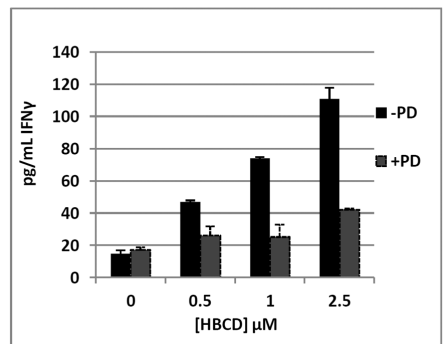

D.

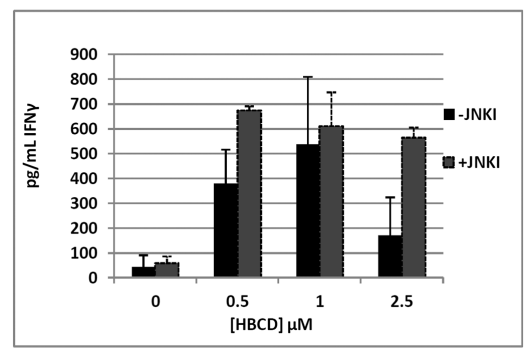

Figure 3.

Effects of $24 \mathrm{~h}$ exposure to $0.5,1$, and $2.5 \mu \mathrm{M}$ HBCD on IFN $\gamma$ secretion from monocytedepleted PBMCs treated with selective enzyme inhibitors in an individual donor. A) NFkB Inhibitor (BAY 11-7085) (donor F273).B) MEK 1/2(p44/42) Inhibitor (PD98059) (donor F254).C) P38 Inhibitor (SB202190) (donor F254).D) JNK inhibitor (donor F271). 
Table 1

Effects of 24 h, 48 h, 6 day exposures to HBCD on IFN $\gamma$ secretion from NK cells.

\begin{tabular}{|r|r|r|r|r|}
\hline $\mathbf{2 4} \mathbf{~ h}$ & \multicolumn{4}{|c|}{ Interferon gamma secreted in pg/mL (mean \pm S.D. $)$} \\
\hline$[\mathrm{HBCD}] \mu \mathrm{M}$ & KB-179 & KB-180 & KB-181 & KB-182 \\
\hline $\mathbf{0}$ & $522 \pm 67$ & $23 \pm 6$ & $19 \pm 0.9$ & $160 \pm 20$ \\
\hline $\mathbf{0 . 0 5}$ & $611 \pm 299$ & $1468 \pm 1233$ & $12 \pm 3^{*}$ & $170 \pm 9$ \\
\hline $\mathbf{0 . 1}$ & $1400 \pm 93^{*}$ & $2629 \pm 179^{*}$ & $7 \pm 0.8^{*}$ & $517 \pm 63^{*}$ \\
\hline $\mathbf{0 . 2 5}$ & $1883 \pm 174^{*}$ & $1956 \pm 993$ & $22 \pm 2$ & $638 \pm 55^{*}$ \\
\hline $\mathbf{0 . 5}$ & $4400 \pm 73^{*}$ & $1151 \pm 1222$ & $9 \pm 3^{*}$ & $2055 \pm 65^{*}$ \\
\hline 1 & $3233 \pm 76^{*}$ & $661 \pm 240^{*}$ & $55 \pm 11^{*}$ & $5182 \pm 319^{*}$ \\
\hline $\mathbf{2 . 5}$ & $206 \pm 42^{*}$ & $195 \pm 149$ & $135 \pm 8^{*}$ & $1120 \pm 75^{*}$ \\
\hline $\mathbf{5}$ & $89 \pm 82^{*}$ & $18 \pm 4$ & $50 \pm 4^{*}$ & $22 \pm 8^{*}$ \\
\hline
\end{tabular}

\begin{tabular}{|r|r|r|r|r|}
\hline $\mathbf{4 8} \mathbf{~ h}$ & \multicolumn{4}{|c|}{ Interferon gamma secreted in pg/mL (mean \pm S.D. $)$} \\
\hline$[$ HBCD] $\boldsymbol{\mu M}$ & KB-179 & KB-180 & KB-181 & KB-182 \\
\hline $\mathbf{0}$ & $1012 \pm 213$ & $460 \pm 27$ & $10 \pm 0.8$ & $256 \pm 4$ \\
\hline $\mathbf{0 . 0 5}$ & $1687 \pm 503$ & $933 \pm 385$ & $12 \pm 1$ & $243 \pm 92$ \\
\hline $\mathbf{0 . 1}$ & $2920 \pm 346^{*}$ & $1263 \pm 102^{*}$ & $15 \pm 3.2$ & $906 \pm 98^{*}$ \\
\hline $\mathbf{0 . 2 5}$ & $5695 \pm 482^{*}$ & $1170 \pm 111^{*}$ & $23 \pm 2^{*}$ & $1550 \pm 84^{*}$ \\
\hline $\mathbf{0 . 5}$ & $12437 \pm 166^{*}$ & $1091 \pm 267$ & $20 \pm 3^{*}$ & $2146 \pm 85^{*}$ \\
\hline $\mathbf{1}$ & $12787 \pm 279^{*}$ & $808 \pm 249$ & $60 \pm 2^{*}$ & $6118 \pm 253^{*}$ \\
\hline $\mathbf{2 . 5}$ & $112 \pm 115^{*}$ & $310 \pm 188$ & $1042 \pm 3^{*}$ & $6140 \pm 408^{*}$ \\
\hline $\mathbf{5}$ & $0 \pm 58^{*}$ & $92 \pm 42^{*}$ & $66 \pm 0.9^{*}$ & $69 \pm 13^{*}$ \\
\hline
\end{tabular}

\begin{tabular}{|r|r|r|r|r|}
\hline $\mathbf{6}$ day & \multicolumn{4}{|c|}{ Interferon gamma secreted in pg/mL (mean \pm S.D. $)$} \\
\hline$[\mathbf{H B C D}] \boldsymbol{\mu M}$ & $\mathbf{K B}-179$ & $\mathbf{K B}-180$ & $\mathbf{K B}-181$ & $\mathbf{K B}-182$ \\
\hline $\mathbf{0}$ & $3246 \pm 177$ & $478 \pm 17$ & $10 \pm 2$ & $383 \pm 10$ \\
\hline $\mathbf{0 . 0 5}$ & $4438 \pm 1634$ & $521 \pm 18^{*}$ & $12 \pm 2$ & $333 \pm 60$ \\
\hline $\mathbf{0 . 1}$ & $4794 \pm 250^{*}$ & $394 \pm 25^{*}$ & $4 \pm 0.6^{*}$ & $465 \pm 44$ \\
\hline $\mathbf{0 . 2 5}$ & $8438 \pm 476^{*}$ & $660 \pm 25^{*}$ & $18 \pm 0.5^{*}$ & $660 \pm 88^{*}$ \\
\hline $\mathbf{0 . 5}$ & $15184 \pm 645^{*}$ & $615 \pm 13^{*}$ & $23 \pm 3^{*}$ & $1607 \pm 231^{*}$ \\
\hline $\mathbf{1}$ & $17015 \pm 128^{*}$ & $551 \pm 17^{*}$ & $106 \pm 3^{*}$ & $8825 \pm 1197^{*}$ \\
\hline $\mathbf{2 . 5}$ & $715 \pm 166^{*}$ & $21 \pm 23^{*}$ & $1348 \pm 76^{*}$ & $9653 \pm 403^{*}$ \\
\hline $\mathbf{5}$ & $351 \pm 104^{*}$ & $8 \pm 11^{*}$ & $267 \pm 14^{*}$ & $3655 \pm 43^{*}$ \\
\hline
\end{tabular}

Values are mean \pm S.D. of triplicate determinations,

indicates a significant difference from control $(\mathrm{p}<0.05)$. 
Table 2

Effects of 24 h, 48 h, 6 day exposures to HBCD on IFN $\gamma$ secretion from MD-PBMCs cells.

\begin{tabular}{|c|c|c|c|c|c|c|}
\hline $24 \mathrm{~h}$ & Interferon & mma secr & ed in $\mathrm{pg} / \mathrm{mL}$ & nean \pm S.D.) & & \\
\hline$[\mathrm{HBCD}] \mu \mathrm{M}$ & F196 & F-197 & F-198 & F-202 & F-204 & F-212 \\
\hline 0 & $2395 \pm 163$ & $38 \pm 2$ & $46 \pm 16$ & $57 \pm 23$ & $98 \pm 27$ & $32 \pm 0.7$ \\
\hline 0.05 & $1777 \pm 309$ & $193 \pm 30^{*}$ & $971 \pm 834$ & $1362 \pm 1280$ & $203 \pm 70$ & $50 \pm 12$ \\
\hline 0.1 & $1910 \pm 133^{*}$ & $160 \pm 34^{*}$ & $1479 \pm 290$ * & $1565 \pm 355^{*}$ & $228 \pm 109$ & $62 \pm 6^{*}$ \\
\hline 0.25 & $1219 \pm 151^{*}$ & $150 \pm 22$ * & $1940 \pm 247^{*}$ & $2963 \pm 1054^{*}$ & $207 \pm 16^{*}$ & $78 \pm 11^{*}$ \\
\hline 0.5 & $2628 \pm 65$ & $140 \pm 31$ * & $1150 \pm 788$ & $1050 \pm 270^{*}$ & $82 \pm 11$ & $125 \pm 9^{*}$ \\
\hline 1 & $2268 \pm 60$ & $172 \pm 61$ & $479 \pm 307$ & $790 \pm 216^{*}$ & $234 \pm 21$ * & $77 \pm 15^{*}$ \\
\hline 2.5 & $3406 \pm 139^{*}$ & $56 \pm 35$ & $371 \pm 65^{*}$ & $433 \pm 116^{*}$ & $373 \pm 63$ * & $314 \pm 9^{*}$ \\
\hline 5 & $1465 \pm 10$ * & $43 \pm 6$ & $148 \pm 12$ * & $75 \pm 37$ & $238 \pm 24$ * & $165 \pm 12^{*}$ \\
\hline
\end{tabular}

\begin{tabular}{|r|r|r|r|r|r|r|}
\hline $\mathbf{4 8} \mathbf{~ h}$ & \multicolumn{7}{|c|}{ Interferon gamma secreted in pg/mL (mean \pm S.D. $)$} & & \\
\hline$[$ HBCD] $\boldsymbol{\mu M}$ & $\mathbf{F - 1 9 6}$ & $\mathbf{F}-197$ & $\mathbf{F}-198$ & $\mathbf{F - 2 0 2}$ & $\mathbf{F - 2 0 4}$ & $\mathbf{F - 2 1 2}$ \\
\hline $\mathbf{0}$ & $2750 \pm 151$ & $61 \pm 2$ & $141 \pm 37$ & $213 \pm 4$ & $165 \pm 6$ & $81 \pm 29$ \\
\hline $\mathbf{0 . 0 5}$ & $1924 \pm 51^{*}$ & $75 \pm 4^{*}$ & $81 \pm 25$ & $388 \pm 275$ & $244 \pm 105$ & $222 \pm 185$ \\
\hline $\mathbf{0 . 1}$ & $2172 \pm 115^{*}$ & $207 \pm 100$ & $150 \pm 33$ & $593 \pm 232$ & $356 \pm 52^{*}$ & $243 \pm 4^{*}$ \\
\hline $\mathbf{0 . 2 5}$ & $4636 \pm 135^{*}$ & $120 \pm 8^{*}$ & $176 \pm 83$ & $538 \pm 29^{*}$ & $507 \pm 36^{*}$ & $214 \pm 44^{*}$ \\
\hline $\mathbf{0 . 5}$ & $4513 \pm 76^{*}$ & $126 \pm 8^{*}$ & $130 \pm 43$ & $472 \pm 52^{*}$ & $440 \pm 167$ & $299 \pm 37^{*}$ \\
\hline $\mathbf{1}$ & $5559 \pm 96^{*}$ & $267 \pm 6^{*}$ & $208 \pm 42$ & $901 \pm 48^{*}$ & $528 \pm 60^{*}$ & $330 \pm 30^{*}$ \\
\hline $\mathbf{2 . 5}$ & $4381 \pm 532^{*}$ & $247 \pm 8^{*}$ & $444 \pm 35^{*}$ & $3044 \pm 27^{*}$ & $851 \pm 15^{*}$ & $2338 \pm 380^{*}$ \\
\hline $\mathbf{5}$ & $2804 \pm 17$ & $0 \pm 1^{*}$ & $330 \pm 41^{*}$ & $222 \pm 13$ & $404 \pm 41^{*}$ & $1239 \pm 49^{*}$ \\
\hline
\end{tabular}

\begin{tabular}{|c|c|c|c|c|c|c|}
\hline 6 day & Interferon gamm & ted in $\mathrm{pg} / \mathrm{r}$ & ean \pm S.D.) & & & \\
\hline$[\mathrm{HBCD}] \mu \mathrm{M}$ & F-196 & F197 & F-198 & F-202 & F-204 & F-212 \\
\hline $\mathbf{0}$ & $1831 \pm 33$ & $119 \pm 0.3$ & $44 \pm 14$ & $423 \pm 95$ & $148 \pm 17$ & $113 \pm 8$ \\
\hline 0.05 & $1050 \pm 248 *$ & $95 \pm 7^{*}$ & $122 \pm 127$ & $4176 \pm 3447$ & $176 \pm 24$ & $488 \pm 263$ \\
\hline 0.1 & $1229 \pm 519$ & $106 \pm 14$ & $65 \pm 20$ & $2377 \pm 2401$ & $156 \pm 32$ & $776 \pm 163$ * \\
\hline 0.25 & $2319 \pm 619$ & $120 \pm 17$ & $92 \pm 47$ & $933 \pm 289$ & $147 \pm 40$ & $639 \pm 118^{*}$ \\
\hline 0.5 & $1729 \pm 60$ & $157 \pm 30$ & $43 \pm 7$ & $1013 \pm 126^{*}$ & $240 \pm 11$ * & $516 \pm 105 *$ \\
\hline 1 & $4676 \pm 1600$ & $521 \pm 80^{*}$ & $62 \pm 15$ & $2034 \pm 262^{*}$ & $325 \pm 12$ * & $315 \pm 27^{*}$ \\
\hline 2.5 & $2362 \pm 112^{*}$ & $494 \pm 91 *$ & $262 \pm 83^{*}$ & $2030 \pm 74^{*}$ & $626 \pm 85^{*}$ & $4011 \pm 398^{*}$ \\
\hline 5 & $1587 \pm 68$ * & $8.2 \pm 1.3^{*}$ & $736 \pm 18$ * & $234 \pm 31$ & $476 \pm 10^{*}$ & $617 \pm 12$ * \\
\hline
\end{tabular}

Values are mean \pm S.D. of triplicate determinations,

indicates a significant difference from control $(\mathrm{p}<0.05)$. 
Table 3

Effects of 24 h, 48 h, 6 day exposures to HBCD on IFN $\gamma$ secretion from PBMCs cells

\begin{tabular}{|r|r|r|r|r|r|}
\hline $\mathbf{2 4} \mathbf{h}$ & \multicolumn{5}{|c|}{ Interferon gamma secreted in pg/mL (mean \pm S.D. $)$} \\
\hline$[$ HBCD] $\boldsymbol{\mu M}$ & $\mathbf{F}-187$ & $\mathbf{F}-189$ & $\mathbf{F}-192$ & $\mathbf{F}-193$ & $\mathbf{F}-195$ \\
\hline $\mathbf{0}$ & $46 \pm 9$ & $416 \pm 29$ & $1001 \pm 18$ & $118 \pm 23$ & $959 \pm 10$ \\
\hline $\mathbf{0 . 0 5}$ & $123 \pm 33^{*}$ & $2008 \pm 376^{*}$ & $1824 \pm 116^{*}$ & $1190 \pm 341^{*}$ & $1127 \pm 181$ \\
\hline $\mathbf{0 . 1}$ & $103 \pm 20^{*}$ & $2304 \pm 250^{*}$ & $1150 \pm 165$ & $432 \pm 77^{*}$ & $916 \pm 52$ \\
\hline $\mathbf{0 . 2 5}$ & $140 \pm 15^{*}$ & $2504 \pm 102^{*}$ & $2557 \pm 175^{*}$ & $306 \pm 53^{*}$ & $972 \pm 27$ \\
\hline $\mathbf{0 . 5}$ & $183 \pm 24^{*}$ & $2997 \pm 325^{*}$ & $1001 \pm 232$ & $304 \pm 107$ & $1420 \pm 59^{*}$ \\
\hline $\mathbf{1}$ & $263 \pm 13^{*}$ & $4229 \pm 84^{*}$ & $1037 \pm 57$ & $268 \pm 96$ & $1229 \pm 181$ \\
\hline $\mathbf{2 . 5}$ & $238 \pm 8^{*}$ & $7292 \pm 242^{*}$ & $1457 \pm 14^{*}$ & $251 \pm 32^{*}$ & $1027 \pm 33$ \\
\hline $\mathbf{5}$ & $274 \pm 25^{*}$ & $847 \pm 65^{*}$ & $396 \pm 17^{*}$ & $91 \pm 14$ & $577 \pm 20^{*}$ \\
\hline
\end{tabular}

\begin{tabular}{|c|c|c|c|c|c|}
\hline $48 \mathrm{~h}$ & Interferon & amma secret & in $\mathrm{pg} / \mathrm{mL}$ & ean \pm S.D.) & \\
\hline$[\mathrm{HBCD}] \mu \mathrm{M}$ & F-187 & F-189 & F-192 & F-193 & F-195 \\
\hline $\mathbf{0}$ & $100 \pm 13$ & $465 \pm 13$ & $889 \pm 37$ & $763 \pm 27$ & $598 \pm 13$ \\
\hline 0.05 & $359 \pm 88$ * & $1146 \pm 57^{*}$ & $2394 \pm 359^{*}$ & $1198 \pm 154^{*}$ & $1095 \pm 55^{*}$ \\
\hline 0.1 & $400 \pm 237$ & $1130 \pm 22^{*}$ & $1604 \pm 235^{*}$ & $1424 \pm 216^{*}$ & $1471 \pm 33^{*}$ \\
\hline 0.25 & $288 \pm 52 *$ & $1607 \pm 21^{*}$ & $1735 \pm 38^{*}$ & $1120 \pm 31^{*}$ & $846 \pm 62$ * \\
\hline 0.5 & $361 \pm 117$ & $2549 \pm 129^{*}$ & $1878 \pm 184^{*}$ & $1346 \pm 173^{*}$ & $728 \pm 124$ \\
\hline 1 & $203 \pm 77$ & $3322 \pm 41$ * & $1505 \pm 67^{*}$ & $1591 \pm 86^{*}$ & $643 \pm 38$ \\
\hline 2.5 & $778 \pm 98$ * & $6577 \pm 127^{*}$ & $421 \pm 21$ * & $2044 \pm 72$ * & $886 \pm 13$ * \\
\hline 5 & $1035 \pm 96^{*}$ & $770 \pm 20$ * & $243 \pm 23^{*}$ & $1487 \pm 56^{*}$ & $248 \pm 46^{*}$ \\
\hline
\end{tabular}

\begin{tabular}{|c|c|c|c|c|c|}
\hline 6 day & Interferon ga & secreted in pg & mean \pm S.D.) & & \\
\hline$[\mathrm{HBCD}] \mu \mathrm{M}$ & F187 & F-189 & F-192 & F-193 & F-195 \\
\hline 0 & $17 \pm 7$ & $236 \pm 9$ & $2791 \pm 48$ & $1404 \pm 30$ & $1217 \pm 107$ \\
\hline 0.05 & $58 \pm 23$ & $1746 \pm 132^{*}$ & $1316 \pm 777$ & $341 \pm 23$ * & $1468 \pm 633$ \\
\hline 0.1 & $23 \pm 10$ & $1600 \pm 164^{*}$ & $2170 \pm 475$ & $874 \pm 49^{*}$ & $194 \pm 40$ * \\
\hline 0.25 & $37 \pm 18$ & $2060 \pm 85^{*}$ & $1701 \pm 246^{*}$ & $617 \pm 28$ * & $1309 \pm 269$ \\
\hline 0.5 & $45 \pm 1^{*}$ & $2057 \pm 689^{*}$ & $2170 \pm 622$ & $959 \pm 65^{*}$ & $1199 \pm 81$ \\
\hline 1 & $85 \pm 5^{*}$ & $2448 \pm 372^{*}$ & $1927 \pm 413$ & $1052 \pm 28$ * & $1853 \pm 51$ * \\
\hline 2.5 & $191 \pm 25^{*}$ & $2051 \pm 57^{*}$ & $809 \pm 86^{*}$ & $1274 \pm 35^{*}$ & $1519 \pm 94 *$ \\
\hline 5 & $225 \pm 7$ * & $490 \pm 102 *$ & $563 \pm 52 *$ & $481 \pm 8^{*}$ & $1209 \pm 1437$ \\
\hline
\end{tabular}

Values are mean \pm S.D. of triplicate determinations,

indicates a significant difference from control $(\mathrm{p}<0.05)$. 
Table 4

Effects of 24 h, 48 h, 6 day exposures to TBBPA on IFN $\gamma$ secretion from NK cells

\begin{tabular}{|r|r|r|r|r|r|}
\hline $\mathbf{2 4} \mathbf{h}$ & \multicolumn{5}{|c|}{ Interferon gamma secreted in pg/mL (mean \pm S.D. $)$} \\
\hline$[$ TBBPA] $\boldsymbol{\mu M}$ & $\mathbf{K B - 1 2 9}$ & $\mathbf{K B}-130$ & $\mathbf{K B}-181$ & KB-183 & KB-184 \\
\hline $\mathbf{0}$ & $378 \pm 12$ & $8497 \pm 206$ & $0 \pm 1.9$ & $1147 \pm 41$ & $39 \pm 2$ \\
\hline $\mathbf{0 . 0 5}$ & $790 \pm 77^{*}$ & $8027 \pm 268$ & $0.3 \pm 0.3$ & $299 \pm 10^{*}$ & $29 \pm 2^{*}$ \\
\hline $\mathbf{0 . 1}$ & $382 \pm 55$ & $7060 \pm 227^{*}$ & $0.2 \pm 0.8$ & $310 \pm 4^{*}$ & $66 \pm 3^{*}$ \\
\hline $\mathbf{0 . 2 5}$ & $45 \pm 61^{*}$ & $1963 \pm 67^{*}$ & $0 \pm 0.3$ & $254 \pm 49^{*}$ & $22 \pm 3^{*}$ \\
\hline $\mathbf{0 . 5}$ & $0 \pm 39^{*}$ & $0 \pm 17^{*}$ & $0 \pm 0.8$ & $73 \pm 15^{*}$ & $5 \pm 1^{*}$ \\
\hline $\mathbf{1}$ & $0 \pm 64^{*}$ & $0 \pm 31^{*}$ & $0 \pm 0.6$ & $47 \pm 1^{*}$ & $4 \pm 3^{*}$ \\
\hline $\mathbf{2 . 5}$ & $0 \pm 3^{*}$ & $0 \pm 6^{*}$ & $0 \pm 1.8$ & $39 \pm 11^{*}$ & $0 \pm 5^{*}$ \\
\hline
\end{tabular}

\begin{tabular}{|r|r|r|r|r|r|}
\hline $\mathbf{4 8} \mathbf{h}$ & \multicolumn{5}{|c|}{ Interferon gamma secreted in pg/mL (mean \pm S.D. $)$} \\
\hline$[$ TBBPA] $\boldsymbol{\mu M}$ & $\mathbf{K B - 1 2 9}$ & $\mathbf{K B}-130$ & $\mathbf{K B}-181$ & KB-183 & KB-184 \\
\hline $\mathbf{0}$ & $3347 \pm 69$ & $11568 \pm 163$ & $22 \pm 0.4$ & $1958 \pm 37$ & $208 \pm 9$ \\
\hline $\mathbf{0 . 0 5}$ & $3147 \pm 275$ & $11882 \pm 727$ & $20 \pm 2$ & $447 \pm 17^{*}$ & $188 \pm 101$ \\
\hline $\mathbf{0 . 1}$ & $1357 \pm 296^{*}$ & $11045 \pm 184^{*}$ & $16 \pm 1.5^{*}$ & $368 \pm 11^{*}$ & $270 \pm 32$ \\
\hline $\mathbf{0 . 2 5}$ & $364 \pm 124^{*}$ & $4960 \pm 31^{*}$ & $22 \pm 2.3$ & $133 \pm 12^{*}$ & $172 \pm 4^{*}$ \\
\hline $\mathbf{0 . 5}$ & $92 \pm 79^{*}$ & $557 \pm 16^{*}$ & $22 \pm 1$ & $29 \pm 6^{*}$ & $91 \pm 12^{*}$ \\
\hline $\mathbf{1}$ & $24 \pm 94^{*}$ & $0 \pm 10^{*}$ & $15 \pm 2^{*}$ & $12 \pm 8^{*}$ & $76 \pm 15^{*}$ \\
\hline $\mathbf{2 . 5}$ & $0 \pm 19^{*}$ & $13 \pm 28^{*}$ & $12 \pm 1^{*}$ & $3 \pm 9^{*}$ & $38 \pm 4^{*}$ \\
\hline $\mathbf{5}$ & $0 \pm 12^{*}$ & $10 \pm 13^{*}$ & $13 \pm 0.4^{*}$ & $3 \pm 4^{*}$ & $32 \pm 7^{*}$ \\
\hline
\end{tabular}

\begin{tabular}{|r|r|r|r|r|r|}
\hline $\mathbf{6}$ day & \multicolumn{5}{|c|}{ Interferon gamma secreted in $\mathbf{~ g g} / \mathbf{m L}(\mathbf{m e a n} \pm$ S.D. $)$} \\
\hline [TBBPA] $\boldsymbol{\mu M}$ & $\mathbf{K B}-129$ & $\mathbf{K B}-130$ & $\mathbf{K B}-181$ & $\mathbf{K B}-183$ & $\mathbf{K B}-184$ \\
\hline $\mathbf{0}$ & $6800 \pm 176$ & $11687 \pm 290$ & $27 \pm 0.7$ & $2248 \pm 39$ & $91 \pm 2$ \\
\hline $\mathbf{0 . 0 5}$ & $3573 \pm 107^{*}$ & $12607 \pm 545$ & $31 \pm 3$ & $987 \pm 67^{*}$ & $148 \pm 14^{*}$ \\
\hline $\mathbf{0 . 1}$ & $2243 \pm 136^{*}$ & $10480 \pm 128^{*}$ & $36 \pm 1^{*}$ & $742 \pm 32^{*}$ & $175 \pm 17^{*}$ \\
\hline $\mathbf{0 . 2 5}$ & $363 \pm 93^{*}$ & $3810 \pm 318^{*}$ & $37 \pm 1.4^{*}$ & $468 \pm 20^{*}$ & $102 \pm 14$ \\
\hline $\mathbf{0 . 5}$ & $0 \pm 137^{*}$ & $678 \pm 30^{*}$ & $32 \pm 0.7^{*}$ & $135 \pm 13^{*}$ & $49 \pm 4^{*}$ \\
\hline $\mathbf{1}$ & $0 \pm 117^{*}$ & $60 \pm 35^{*}$ & $25 \pm 1.1$ & $135 \pm 5^{*}$ & $25 \pm 8^{*}$ \\
\hline $\mathbf{2 . 5}$ & $0 \pm 46^{*}$ & $32 \pm 19^{*}$ & $23 \pm 0 *$ & $125 \pm 18^{*}$ & $13 \pm 3^{*}$ \\
\hline $\mathbf{5}$ & $0 \pm 55^{*}$ & $25 \pm 5^{*}$ & $26 \pm 0.4^{*}$ & $133 \pm 3^{*}$ & $17 \pm 1^{*}$ \\
\hline
\end{tabular}

Values are mean \pm S.D. of triplicate determinations,

indicates a significant difference from control $(\mathrm{p}<0.05)$. 
Table 5

Effects of 24 h, 48 h, 6 day exposures to TBBPA on IFN $\gamma$ secretion from MD-PBMCs cells.

\begin{tabular}{|r|r|r|r|}
\hline $\mathbf{2 4} \mathbf{h}$ & \multicolumn{3}{|c|}{ Interferon gamma secreted in pg/mL (mean \pm S.D. $)$} \\
\hline$[$ TBBPA] $\boldsymbol{\mu M}$ & $\mathbf{F - 1 7 5}$ & $\mathbf{F}-177$ & $\mathbf{F}-180$ \\
\hline $\mathbf{0}$ & $213 \pm 10$ & $109 \pm 2$ & $64 \pm 2$ \\
\hline $\mathbf{0 . 0 5}$ & $190 \pm 28$ & $87 \pm 27$ & $1302 \pm 195^{*}$ \\
\hline $\mathbf{0 . 1}$ & $73 \pm 12^{*}$ & $28 \pm 1^{*}$ & $812 \pm 124^{*}$ \\
\hline $\mathbf{0 . 2 5}$ & $147 \pm 24^{*}$ & $45 \pm 10^{*}$ & $697 \pm 460$ \\
\hline $\mathbf{0 . 5}$ & $13 \pm 33^{*}$ & $0 \pm 9^{*}$ & $58 \pm 40$ \\
\hline $\mathbf{1}$ & $0 \pm 2^{*}$ & $0 \pm 1^{*}$ & $87 \pm 92$ \\
\hline $\mathbf{2 . 5}$ & $0 \pm 13^{*}$ & $0 \pm 5^{*}$ & $39 \pm 45$ \\
\hline $\mathbf{5}$ & $6 \pm 22^{*}$ & $0 \pm 3^{*}$ & $2 \pm 2^{*}$ \\
\hline
\end{tabular}

\begin{tabular}{|r|r|r|r|}
\hline $\mathbf{4 8} \mathbf{~ h}$ & \multicolumn{3}{|c|}{ Interferon gamma secreted in $\mathbf{~ p g} / \mathbf{m L}(\mathbf{m e a n} \pm$ S.D. $)$} \\
\hline [TBBPA] $\boldsymbol{\mu M}$ & $\mathbf{F - 1 7 5}$ & $\mathbf{F}-177$ & $\mathbf{F - 1 8 0}$ \\
\hline $\mathbf{0}$ & $44 \pm 4$ & $2513 \pm 78$ & $436 \pm 2$ \\
\hline $\mathbf{0 . 0 5}$ & $746 \pm 19^{*}$ & $357 \pm 31^{*}$ & $151 \pm 32^{*}$ \\
\hline $\mathbf{0 . 1}$ & $510 \pm 85^{*}$ & $457 \pm 140^{*}$ & $372 \pm 66$ \\
\hline $\mathbf{0 . 2 5}$ & $136 \pm 80$ & $587 \pm 181^{*}$ & $264 \pm 30^{*}$ \\
\hline $\mathbf{0 . 5}$ & $178 \pm 174$ & $647 \pm 55^{*}$ & $233 \pm 11^{*}$ \\
\hline 1 & $49 \pm 14$ & $900 \pm 111^{*}$ & $409 \pm 41$ \\
\hline $\mathbf{2 . 5}$ & $0 \pm 6^{*}$ & $443 \pm 15^{*}$ & $122 \pm 17^{*}$ \\
\hline $\mathbf{5}$ & $0 \pm 54$ & $353 \pm 12^{*}$ & $132 \pm 5^{*}$ \\
\hline
\end{tabular}

\begin{tabular}{|r|r|r|r|}
\hline $\mathbf{6}$ day & \multicolumn{3}{|c|}{ Interferon gamma secreted in pg/mL (mean \pm S.D. $)$} \\
\hline$[$ TBBPA] $\boldsymbol{\mu M}$ & $\mathbf{F - 1 7 5}$ & $\mathbf{F - 1 7 7}$ & $\mathbf{F}-180$ \\
\hline $\mathbf{0}$ & $617 \pm 17$ & $6917 \pm 146$ & $210 \pm 14$ \\
\hline $\mathbf{0 . 0 5}$ & $668 \pm 10^{*}$ & $2525 \pm 2186$ & $175 \pm 8^{*}$ \\
\hline $\mathbf{0 . 1}$ & $593 \pm 32$ & $2125 \pm 284^{*}$ & $127 \pm 2^{*}$ \\
\hline $\mathbf{0 . 2 5}$ & $482 \pm 13^{*}$ & $2417 \pm 594^{*}$ & $115 \pm 4^{*}$ \\
\hline $\mathbf{0 . 5}$ & $322 \pm 13^{*}$ & $1717 \pm 72^{*}$ & $95 \pm 3^{*}$ \\
\hline $\mathbf{1}$ & $299 \pm 17^{*}$ & $871 \pm 51^{*}$ & $96 \pm 10^{*}$ \\
\hline $\mathbf{2 . 5}$ & $96 \pm 35^{*}$ & $350 \pm 99^{*}$ & $49 \pm 2.5^{*}$ \\
\hline $\mathbf{5}$ & $0 \pm 10^{*}$ & $133 \pm 31^{*}$ & $16 \pm 3^{*}$ \\
\hline
\end{tabular}

Values are mean \pm S.D. of triplicate determinations,

indicates a significant difference from control $(\mathrm{p}<0.05)$. 
Table 6

Effects of 24 h, 48 h, 6 day exposures to TBBPA on IFN $\gamma$ secretion from PBMCs cells

\begin{tabular}{|r|c|c|c|c|c|}
\hline \multicolumn{1}{|l|}{$\mathbf{2 4} \mathbf{h}$} & \multicolumn{5}{|c|}{ Interferon gamma secreted in pg/mL (mean \pm S.D. $)$} \\
\hline$[$ TBBPA] $\boldsymbol{\mu M}$ & $\mathbf{F 1 8 6}$ & $\mathbf{F - 1 8 7}$ & $\mathbf{F - 1 8 8}$ & $\mathbf{F}-193$ & F-194 \\
\hline $\mathbf{0}$ & $65 \pm 8$ & $101 \pm 7$ & $647 \pm 12$ & $333 \pm 3$ & $525 \pm 18$ \\
\hline $\mathbf{0 . 0 5}$ & $59 \pm 4$ & $126 \pm 16$ & $330 \pm 201$ & $474 \pm 91$ & $532 \pm 248$ \\
\hline $\mathbf{0 . 1}$ & $73 \pm 0.9$ & $121 \pm 6^{*}$ & $307 \pm 83^{*}$ & $239 \pm 55$ & $532 \pm 54$ \\
\hline $\mathbf{0 . 2 5}$ & $72 \pm 22$ & $111 \pm 15$ & $447 \pm 140$ & $150 \pm 47^{*}$ & $290 \pm 48^{*}$ \\
\hline $\mathbf{0 . 5}$ & $55 \pm 8$ & $108 \pm 4$ & $287 \pm 12^{*}$ & $90 \pm 59^{*}$ & $182 \pm 38^{*}$ \\
\hline $\mathbf{1}$ & $53 \pm 5$ & $82 \pm 12$ & $230 \pm 17^{*}$ & $69 \pm 27^{*}$ & $72 \pm 16^{*}$ \\
\hline $\mathbf{2 . 5}$ & $72 \pm 8$ & $178 \pm 37$ & $203 \pm 21^{*}$ & $151 \pm 61^{*}$ & $93 \pm 33^{*}$ \\
\hline $\mathbf{5}$ & $55 \pm 7$ & $141 \pm 18^{*}$ & $83 \pm 6^{*}$ & $146 \pm 17^{*}$ & $95 \pm 5^{*}$ \\
\hline
\end{tabular}

\begin{tabular}{|r|r|r|r|r|r|}
\hline \multicolumn{4}{|l|}{$\mathbf{4 8} \mathbf{~ h}$} & \multicolumn{4}{|l|}{ Interferon gamma secreted in pg/mL (mean \pm S.D. $)$} & \\
\hline$[$ TBBPA] $\mathbf{\mu M}$ & $\mathbf{F - 1 8 6}$ & $\mathbf{F - 1 8 7}$ & $\mathbf{F}-\mathbf{1 8 8}$ & $\mathbf{F}-193$ & $\mathbf{F}-194$ \\
\hline $\mathbf{0}$ & $47 \pm 7$ & $47 \pm 2$ & $326 \pm 5$ & $829 \pm 14$ & $693 \pm 8$ \\
\hline $\mathbf{0 . 0 5}$ & $265 \pm 195$ & $312 \pm 195$ & $287 \pm 50$ & $1083 \pm 62^{*}$ & $2250 \pm 58^{*}$ \\
\hline $\mathbf{0 . 1}$ & $359 \pm 169$ & $105 \pm 41$ & $300 \pm 87$ & $1050 \pm 45^{*}$ & $2767 \pm 55^{*}$ \\
\hline $\mathbf{0 . 2 5}$ & $133 \pm 106$ & $36 \pm 9$ & $220 \pm 3^{*}$ & $1204 \pm 56^{*}$ & $493 \pm 14^{*}$ \\
\hline $\mathbf{0 . 5}$ & $65 \pm 23$ & $28 \pm 0.8^{*}$ & $114 \pm 10^{*}$ & $1471 \pm 26^{*}$ & $322 \pm 16^{*}$ \\
\hline $\mathbf{1}$ & $45 \pm 5$ & $30 \pm 2^{*}$ & $11 \pm 19^{*}$ & $629 \pm 19^{*}$ & $217 \pm 61^{*}$ \\
\hline $\mathbf{2 . 5}$ & $53 \pm 5$ & $55 \pm 1.5^{*}$ & $13 \pm 12^{*}$ & $717 \pm 38^{*}$ & $190 \pm 58^{*}$ \\
\hline $\mathbf{5}$ & $40 \pm 5$ & $64 \pm 0.8^{*}$ & $3 \pm 6^{*}$ & $471 \pm 19^{*}$ & $58 \pm 26^{*}$ \\
\hline
\end{tabular}

\begin{tabular}{|c|c|c|c|c|c|}
\hline 6 day & Interferon gam & la secreted in pg & nL (mean \pm S.D. $)$ & & \\
\hline [TBBPA] $\mu \mathrm{M}$ & F-186 & F-187 & F-188 & F-193 & F-194 \\
\hline 0 & $68 \pm 4$ & $58 \pm 0.6$ & $370 \pm 9$ & $644 \pm 19$ & $1408 \pm 24$ \\
\hline 0.05 & $56 \pm 21$ & $46 \pm 7$ & $409 \pm 20$ & $433 \pm 48$ * & $1502 \pm 21$ * \\
\hline 0.1 & $114 \pm 9^{*}$ & $49 \pm 3 *$ & $363 \pm 23$ & $396 \pm 23^{*}$ & $2503 \pm 68^{*}$ \\
\hline 0.25 & $63 \pm 9$ & $46 \pm 1.2^{*}$ & $198 \pm 2^{*}$ & $389 \pm 19^{*}$ & $1370 \pm 46$ \\
\hline 0.5 & $62 \pm 11$ & $58 \pm 6$ & $214 \pm 8^{*}$ & $259 \pm 6^{*}$ & $972 \pm 150$ " \\
\hline 1 & $51 \pm 3 *$ & $85 \pm 4 *$ & $92 \pm 13^{*}$ & $282 \pm 28^{*}$ & $667 \pm 29^{*}$ \\
\hline 2.5 & $46 \pm 6^{*}$ & $48 \pm 2 *$ & $149 \pm 17^{*}$ & $356 \pm 44^{*}$ & $465 \pm 23^{*}$ \\
\hline 5 & $34 \pm 0.9^{*}$ & $90 \pm 7^{*}$ & $93 \pm 12^{*}$ & $344 \pm 29^{*}$ & $62 \pm 18$ \\
\hline
\end{tabular}

Values are mean \pm S.D. of triplicate determinations,

indicates a significant difference from contro $(\mathrm{p}<0.05)$. 


\section{Table 7}

Effects of $24 \mathrm{~h}$ exposure to HBCD +/- Pathway inhibitors on IFN $\gamma$ secretion from MD-PBMCs.

NFKB Inhibitor (BAY 11-7085)

\begin{tabular}{rllll}
$\mathbf{2 4} \mathbf{h}$ & \multicolumn{5}{l}{ Interferon gamma secreted in pg/mL (mean \pm S.D. $)$} \\
\hline$[$ HBCD $\boldsymbol{\mu M}$ & $\mathrm{F}-273$ & $\mathrm{~F}-275$ & $\mathrm{~F}-289$ & $\mathrm{~F}-293$ \\
$\mathbf{0}$ & $55 \pm 1$ & $84 \pm 5$ & $49 \pm 1$ & $141 \pm 4$ \\
$\mathbf{0}+\mathbf{B A Y}$ & $21 \pm 1$ & $59 \pm 4$ & $20 \pm 2$ & $23 \pm 5$ \\
$\mathbf{0 . 5}$ & $97 \pm 4^{*}$ & $101 \pm 7^{*}$ & $37 \pm 5^{*}$ & $160 \pm 10$ \\
$\mathbf{0 . 5}+\mathbf{B A Y}$ & $86 \pm 16^{* *}$ & $0 \pm 13^{* *}$ & $9 \pm 1^{*}$ & $11 \pm 2^{*}$ \\
$\mathbf{1}$ & $150 \pm 6^{*}$ & $154 \pm 8^{*}$ & $52 \pm 1$ & $168 \pm 10^{*}$ \\
$\mathbf{1}+\mathbf{B A Y}$ & $62 \pm 11^{* *}$ & $0 \pm 15^{* *}$ & $11 \pm 0 *$ & $25 \pm 2$ \\
$\mathbf{2 . 5}$ & $317 \pm 12^{*}$ & $180 \pm 9^{*}$ & $319 \pm 0.5^{*}$ & $441 \pm 37^{*}$ \\
$\mathbf{2 . 5}+\mathbf{B A Y}$ & $46 \pm 13$ & $90 \pm 21$ & $126 \pm 3^{*}$ & $223 \pm 64^{*}$ \\
\hline & & &
\end{tabular}

\begin{tabular}{rllll}
24 h & \multicolumn{4}{c}{ Interferon gamma secreted in pg/mL (mean \pm S.D. $)$} \\
\hline [HBCD] $\mathbf{\mu M}$ & F- 253 & F- 254 & F-263 & F-265 \\
$\mathbf{0}$ & $15 \pm 2$ & $54 \pm 7$ & $15 \pm 5$ & $9 \pm 0.6$ \\
$\mathbf{0}+\mathbf{P D}$ & $17 \pm 2$ & $21 \pm 0.3$ & $17 \pm 10$ & $24 \pm 4$ \\
$\mathbf{0 . 5}$ & $47 \pm 1^{*}$ & $88 \pm 3^{*}$ & $61 \pm 3^{*}$ & $56 \pm 6^{*}$ \\
$\mathbf{0 . 5}+\mathbf{P D}$ & $26 \pm 6$ & $27 \pm 5$ & $39 \pm 22$ & $106 \pm 15^{* *}$ \\
$\mathbf{1}$ & $74 \pm 0.8^{*}$ & $66 \pm 2$ & $60 \pm 9^{*}$ & $46 \pm 6^{*}$ \\
$\mathbf{1}+\mathbf{P D}$ & $25 \pm 8$ & $46 \pm 2^{* *}$ & $66 \pm 10^{* *}$ & $96 \pm 6^{* *}$ \\
$\mathbf{2 . 5}$ & $111 \pm 7^{*}$ & $246 \pm 7^{*}$ & $119 \pm 6^{*}$ & $66 \pm 9^{*}$ \\
$\mathbf{2 . 5}+\mathbf{P D}$ & $42 \pm 0.4^{* *}$ & $45 \pm 7^{* *}$ & $69 \pm 13^{* *}$ & $74 \pm 27$
\end{tabular}

p38 Inhibitor (SB202190)

\begin{tabular}{rllll}
$\mathbf{2 4} \mathbf{h}$ & \multicolumn{5}{l}{ Interferon gammasecreted in pg/mL } & $(\mathbf{m e a n} \pm$ S.D. $)$ \\
\hline$[$ HBCD] $\boldsymbol{\mu M}$ & $\mathrm{F}-254$ & $\mathrm{~F}-255$ & $\mathrm{~F}-263$ & $\mathrm{~F}-265$ \\
$\mathbf{0}$ & $35 \pm 0.6$ & $11 \pm 3$ & $269 \pm 13$ & $75 \pm 3$ \\
$\mathbf{0}+\mathbf{S B}$ & $6 \pm 0.3$ & $11 \pm 4$ & $52 \pm 10$ & $125 \pm 55$ \\
$\mathbf{0 . 5}$ & $80 \pm 5^{*}$ & $27 \pm 4^{*}$ & $5351 \pm 134^{*}$ & $1451 \pm 234^{*}$ \\
$\mathbf{0 . 5}+\mathbf{S B}$ & $54 \pm 4^{* *}$ & $104 \pm 32^{* *}$ & $956 \pm 363^{* *}$ & $1292 \pm 133^{* *}$ \\
$\mathbf{1}$ & $87 \pm 3^{*}$ & $20 \pm 2^{*}$ & $490 \pm 61^{*}$ & $1407 \pm 871$ \\
$\mathbf{1 +} \mathbf{S B}$ & $46 \pm 15^{* *}$ & $69 \pm 8^{* *}$ & $685 \pm 62^{* *}$ & $1416 \pm 234^{* *}$ \\
$\mathbf{2 . 5}$ & $121 \pm 9^{*}$ & $29 \pm 9^{*}$ & $1837 \pm 189^{*}$ & $348 \pm 131$ \\
$\mathbf{2 . 5}+\mathbf{S B}$ & $16 \pm 3^{* *}$ & $64 \pm 23^{* *}$ & $639 \pm 86^{* *}$ & $1473 \pm 95^{* *}$ \\
\hline
\end{tabular}


JNK Inhibitor (BI78D3)

\begin{tabular}{rllll}
$\mathbf{2 4} \mathbf{h}$ & \multicolumn{4}{l}{ Interferon gamma secreted in pg/mL } \\
\hline [HBCD $] \boldsymbol{\mu M}$ & $\mathrm{F}-271$ & $\mathrm{~F}-273$ & $\mathrm{~F}-275$ & $\mathrm{~F}-278$ \\
$\mathbf{0}$ & $65 \pm 4$ & $116 \pm 5$ & $19 \pm 0.7$ & $45 \pm 46$ \\
$\mathbf{0}+\mathbf{J N K}$ & $16 \pm 3$ & $61 \pm 2$ & $15 \pm 0.4$ & $58 \pm 28$ \\
$\mathbf{0 . 5}$ & $104 \pm 8^{*}$ & $203 \pm 14^{*}$ & $24 \pm 3$ & $381 \pm 135^{*}$ \\
$\mathbf{0 . 5}+\mathbf{J N K}$ & $237 \pm 20^{* *}$ & $119 \pm 13^{* *}$ & $26 \pm 13$ & $674 \pm 17^{* *}$ \\
$\mathbf{1}$ & $251 \pm 44^{*}$ & $195 \pm 10^{*}$ & $24 \pm 0.8^{*}$ & $538 \pm 271$ \\
$\mathbf{1 +} \mathbf{J N K}$ & $306 \pm 69^{* *}$ & $160 \pm 15^{* *}$ & $23 \pm 1^{* *}$ & $610 \pm 137^{* *}$ \\
$\mathbf{2 . 5}$ & $140 \pm 13^{*}$ & $515 \pm 14^{*}$ & $40 \pm 3^{*}$ & $172 \pm 152$ \\
$\mathbf{2 . 5}+\mathbf{J N K}$ & $53 \pm 1^{* *}$ & $153 \pm 3^{* *}$ & $31 \pm 3^{* *}$ & $565 \pm 40^{* *}$ \\
\hline
\end{tabular}

Values are mean \pm S.D. of triplicate determinations.

indicates a significant increase compared to no $\operatorname{HBCD}(0), \mathrm{p}<0.05$; **

indicates a significant increase compared to no HBCD + inhibitor 